\title{
Growth Strategies of Media Companies: Efficiency Analysis
}

\author{
Mercedes Medina ${ }^{1}$ \\ Alfonso Sánchez-Tabernero² \\ Arturo Larrainzar ${ }^{3}$
}

Recibido: 12/11/2018

Aprobado por pares: 06/12/2018
Enviado a pares: $12 / 11 / 2018$

Aceptado: 13/02/2019

DOI: 10.5294/pacla.2020.23.1.7

To reference this paper / para citar este artículo / para citar este artigo Medina, M., Sánchez-Tabernero, A., \& Larrainzar, A. (2020). Growth strategies of media companies: Efficiency analysis. Palabra Clave, 23(1), e2317. DOI: https://doi.org/10.5294/ pacla.2020.23.1.7

\section{Abstract}

This paper analyzes the media and entertainment companies' main strategic options about what to do for growing — internationalization or diversification - and how to do it - organic and inorganic growth - in a context of ever growing competition. We identify correlations between those strategies and three basic pillars of managers' decision-making process: growth, profitability, and indebtedness. We conclude that mergers and acquisitions can generate rapid growth, but they are expensive in terms of Return on Investment Capital (ROIC) and they usually increase the leverage of the company. Therefore, the inorganic path could not be the best option for companies with difficulties to get access to capital or for very cyclical businesses. In addition, we identify that vertical integration generates a lower ROIC than horizontal integration, and we show how internationalization strategies increase the profitability of audiovisual companies. We analyze the basic indicators of 50 listed companies in the sector that meet three criteria necessary for our study: data transparency, sufficient size of the

\footnotetext{
https://orcid.org/0000-0003-1754-6811. Universidad de Navarra, Spain. mmedina@unav.es

2 https://orcid.org/0000-0003-3392-1861. Universidad de Navarra, Spain. astabernero@unav.es

3 https://orcid.org/0000-0002-5640-2311. Atresmedia, Spain. arturo.larrainzar@atresmedia.com
} 
company, and a certain trajectory that would allow us to study the consequences of the chosen strategies over long periods of time, at least 15 years. We study the firms' evolution from 2010 to 2016 with metrics from the Thomson Reuters database. In that last year, they accounted for 88 percent of global television revenue.

\section{Keywords (Source: Unesco Thesaurus)}

Communication administration; economics of communication; merger; acquisitions; competition; international trade; digitization. 


\section{Estrategias de crecimiento de las empresas de medios: análisis de eficiencia}

\section{Resumen}

Este artículo analiza las principales opciones estratégicas de las empresas de medios y entretenimiento sobre qué hacer para crecer - internacionalización o diversificación - y cómo hacerlo - crecimiento orgánico e inorgánico - en un contexto de competencia cada vez mayor. Identificamos correlaciones entre dichas estrategias y tres pilares básicos del proceso de toma de decisiones de los gerentes: crecimiento, rentabilidad y endeudamiento. Se concluye que las fusiones y las adquisiciones pueden generar un rápido crecimiento, pero son costosas en términos de Retorno sobre el Capital de Inversión (ROIC) y generalmente aumentan el apalancamiento de la empresa. Por consiguiente, la vía inorgánica no podría ser la mejor opción para las empresas con dificultades para acceder al capital o para negocios muy cíclicos. Adicionalmente, se identifica que la integración vertical genera un ROIC más bajo que la integración horizontal, y se muestra cómo las estrategias de internacionalización aumentan la rentabilidad de las empresas audiovisuales. Se analizan los indicadores básicos de 50 empresas cotizadas en el sector que cumplen con tres criterios necesarios para nuestro estudio: transparencia de datos, tamaño suficiente de la empresa y una cierta trayectoria que nos permitiría estudiar las consecuencias de las estrategias escogidas durante largos períodos de tiempo, al menos 15 años. Se estudia la evolución de las empresas entre los años 2010 y 2016 con métricas de la base de datos de Thomson Reuters. En ese último año, representaron el 88 por ciento de los ingresos mundiales de televisión.

\section{Palabras clave (Fuente: tesauro de la Unesco)}

Administración de comunicaciones; economía de la comunicación; fusión; adquisiciones; competencia; comercio internacional; digitalización. 


\section{Estratégias de crescimento das empresas de mídia: análise de eficiência}

\section{Resumo}

Este artigo analisa as principais opções estratégicas das empresas de mídia e entretenimento sobre o que fazer para crescer — internacionalização ou diversificação - e como fazê-lo — crescimento orgânico e inorgânico em um contexto de crescente concorrência. Identificam-se correlações entre essas estratégias e três pilares básicos do processo de tomada de decisões dos gerentes: crescimento, rentabilidade e endividamento. Conclui-se que as fusões e as aquisições podem gerar crescimento rápido, mas são caras em termos de Retorno do Investimento (ROIC) e geralmente aumentam a alavancagem da empresa. Portanto, o crescimento inorgânico não poderia ser a melhor opção para empresas com dificuldades de acesso ao capital ou para negócios muito cíclicos. Além disso, identifica-se que a integração vertical gera um ROIC menor que a integração horizontal e mostra-se como as estratégias de internacionalização aumentam o rendimento das empresas audiovisuais. Analisam-se os indicadores básicos de 50 empresas listadas no setor que atendem a três critérios necessários para o nosso estudo: transparência de dados, tamanho suficiente da empresa e uma trajetória que nos permitiria estudar as consequências das estratégias escolhidas por longos períodos de tempo, pelo menos 15 anos. Estuda-se a evolução das empresas entre 2010 e 2016 com métricas do banco de dados Thomson Reuters. Nesse último ano, representaram $88 \%$ da receita mundial de televisão.

\section{Palavras-chave (Fonte: tesauro da Unesco)}

Administração de comunicações; economia da comunicação; fusão; aquisições; concorrência; comércio internacional; digitalização. 


\section{Introduction}

One of the most innovative aspects of media markets is the weakening of barriers to entry: Digital technology facilitates the emergence of new competitors because the "cost of entry" has declined dramatically (Chon, Choi, Barnett, Danowski, \& Joo, 2003). According to Doyle (2018), "changing technological and market dynamics have accentuated the importance of configuration-scale and corporate structure-as a critical success factor" (p. 8). Previous legal barriers to entry in the areas of content production and distribution are no longer insurmountable. From a company perspective, this change has two fundamental consequences: On the one hand, it is increasingly difficult to maintain market share in one's own territory; but, on the other hand, it is easier to penetrate other markets. Therefore, strategies for growth emerge as the most effective way of preventing company decline.

During the last decade, both the consumption of information and entertainment contents and investment in media advertising have grown worldwide. Total worldwide entertainment and media revenues are expected to rise at a compound annual growth rate (CAGR) of $4.4 \%$ in nominal terms over the course of five years, from USD1.72 trillion in 2015 to USD2.14 trillion in 2020 ( $\mathrm{PwC}, 2016$ ). Therefore, the macroeconomic data imply that it would be reasonable for communication companies to re-invest at least part of their surplus profits in their own sector.

However, this line of reasoning cannot mask another striking fact in this context: The increasing investment potential of the communications sector is shadowed by the decline of many of the media and entertainment companies that led their respective national markets over the last number of years. This paradox may be accounted for as follows: While the industry affords major opportunities to innovative organizations, it also leaves more conservative companies at a profound disadvantage, whereby the latter endeavor - mistakenly — to preserve their past glories.

Economic theory in general, as well as discussions of the communication sector in particular, has been marked for some time by discussions of the advantages and disadvantages of a company being larger than its com- 
petitors. The empirical findings of published research in this regard prove inconclusive: The results vary in relation to the specific conditions of competition and strategies for growth facing or adopted by each company (Oliver, 2014; Carayannis \& Rakhmatullin, 2014; Esser, 2016; Peltier, 2004). Likewise, there is no conclusive evidence as to which model of growth may afford the greatest competitive edge in relation to the specific characteristics of each market.

The purpose of this paper is to explore what approaches may enable the highest expectations of profitability for media companies in a new context shaped by increasingly intense competition and the correspondingly increased difficulty in retaining a leadership position in the market. The first section comprises an overview of the pros and cons of different strategies for growth. Our hypotheses, based on the specific characteristics and conditions of the communications sector, are framed in the following section. Then, the basic indicators of 50 major companies in the industry are analyzed to assess correlations between strategies for growth and financial efficiency and profitability. Finally, the limitations of this research are outlined, along with some proposals for future study that might complete the conclusions drawn here.

\section{The Bigger, the Better?}

For many years, classical economics has held that, by increasing in size, a company may obtain considerable advantages: It can achieve economies of scale and scope, synergies, safeguards for its markets, diversification of risks, become more appealing to its employees, and enhance its name, reputation and negotiating power (Stigler, 1958; Krugman, 1980; Buzzell, Gale, \& Sultan, 1975; Schmalensee, 1981; Lawler, 1997; Chalaby, 2018). Mergers and acquisitions are the inevitable step for achieving a superior position in the market and maximizing revenue streams (Evens \& Donders, 2016). In fact, companies refuse opportunities for growth in only two scenarios: (i) when they have recently grown and need time to assimilate the change in size before expanding further (for instance, accommodating a newly acquired unit or area within an internal corporate culture); and (ii) when they are faced with serious problems, such as a loss of profitability, damage to corporate 
reputation or other severe financial difficulties that require the undivided attention of company management. In boom times, by contrast, company management tends to ignore the question of whether or not growth is desirable, to focus directly on how such growth should be brought about.

Nevertheless, all forms of growth involve challenges. For Aldrich and Auster (1986), the main difficulty comes from the characteristic resistance to change, which is inevitable in large organizations. Other researchers (e.g., Allocca \& Kessler, 2006) point out that growth in company size leads to increased bureaucracy and that it may slow managerial decision-making processes. Moreover, inorganic growth tends to lead to greater debt and corporate culture clashes between organizations (Schwartz \& Davis, 1981; Kerr \& Slocum, 1987). Finally, many growth strategies may blur the focus or undercut the specialization of the companies involved (Matsusaka, 2001). For Van Kranenburg and Ziggers (2018), "empirical evidence shows that many M\&As fail to create value or even destroy value” (p. 214).

From the point of view of strategic decision-making, the most judicious theoretical model consists of exploiting all the potential advantages of growth while simultaneously avoiding any and all of the kinds of collateral damage referred to above (Coad, Daunfeldt, Hölzl, Johansson, \& Nightingale, 2014; Roos \& von Krogh, 2016). Such an objective may not be achievable in practice, leading to divestment and, in some cases, the division of the company into two or more parts so as to safeguard the interests of shareholders. Recent examples of this phenomenon include AOL-Time Warner, Gannett, News Corp, Scripps, Tribune, and Viacom.

\section{Strategies for Growth}

Indeed, strategies for growth involve both advantages and disadvantages at the same time; assessment of the real impact of each strategy, in the short as well as long term, requires close analysis of how each model might function in the market of a given product or service. Even then, however, the indicators obtained may depend on other factors that are difficult to separate out, such as the way each strategy is implemented, the reactions of competitors, and/or the overall development of the market. 
Strategies for growth are based on five basic decisions (Carman \& Langeard, 1980; Cronin \& Page, 1988):

a. Inorganic or organic growth. In the former, companies increase their size through mergers or acquisitions; in the latter, they grow by launching on the market ideas that stem from innovative projects devised by the employees.

b. Vertical or horizontal integration. Through the first type of integration, companies are present at various stages of the value chain; the other option consists of accumulating several business units in the same phase of the chain (production, or content packaging, or distribution).

c. Internationalization or permanence in the national market. International growth means exporting formulas successfully developed in the original market. Alternatively, a company may decide not to move into other countries, electing instead to leverage their relationships and knowledge in the existing market in order to grow.

d. Content variety (news, fiction, entertainment) or specialization. The first option establishes fewer limits to growth, while the second choice makes it easier for companies to be experts in the production of a particular type of content.

e. A single-device offer or a multiplatform offer. Companies that distribute content on only one medium miss out on the opportunity to use other channels, but they save on the cost of acquiring or renting such channels.

The strategies for growth are more complicated because not all of the five strategic decisions listed above are mutually exclusive or they may cease to be so over time: For instance, a company may embark on a process of vertical integration, before later deciding to implement a horizontal form of integration as well; moreover, having acquired another company (inorganic growth) may also decide to launch a new product or service on the market (organic growth).

There are a number of specific circumstances in the media sector that may condition strategies for growth. A number of these conditions and their potential impact on the five strategic decisions are outlined below. 
First, the media industry-especially the audiovisual sector-has traditionally been a highly regulated industry; therefore, many companies have only been able to increase in size by means of inorganic growth (Hendriks, 1995; Chalaby, 2016). Although the print media have not been subject to such legal restrictions, the high barriers to entry in terms of distribution function as a strict limit on organic growth (Carvajal \& García Avilés, 2008). Nevertheless, the development of the internet (a relatively unregulated space with low barriers to entry) has tipped the scale between organic and inorganic growth.

Second, vertical integration has been more common in the audiovisual sector than in print media because the former has encountered a higher number of bottlenecks in the value chain than the latter (Evens \& Donders, 2016). However, given that digital technology facilitates the distribution of audiovisual contents, many companies no longer see a need to engage in extensive vertical integration, which requires significant investment and may lead to a loss of specialization (Storper, 1989; Wirtz, 2001; Yoo, 2002; Chalaby, 2016) or at least it affects the investment in the content, lowering the quality produced (D’Annunzio, 2017).

International strategies are more prevalent among media companies specialising in entertainment products (music, cinema, fiction production for TV) because such contents and brands "translate" more easily to markets in other countries and contexts. In contrast, news-based contents tend to depend on proximity in terms of perspective and/or context; in fact, most news-journalism media brands establish a high percentage of their sales volumes within their domestic markets (Albarran \& Dimmick, 1996; Casero-Ripollés \& Izquierdo-Castillo, 2013).

In terms of product and/or service specialization, most media companies opt for a diversification rather than a specialization strategy (Chan-Olmsted \& Chang, 2003). The rationale for this approach is based on making the best use of both tangible assets (production processes and distribution systems) and intangible values (knowledge, relationships, brands) to increase sales and profitability (Kolo \& Vogt, 2003). But, as Jung and Chan 
(2015) point out, a high degree of unrelated diversification might decrease performance. There also appears to be a hurdle level for diversification, prior to which expanding businesses in product and international markets may need considerable investment and produce negative cash flow.

Finally, media companies have moved from single-device (paper, airwaves, cable, satellite, or the Internet) to multiplatform content distribution systems. Two main reasons account for this shift (Doyle, 2015; Schlesinger \& Doyle, 2015): the increase in distribution options, in some cases, faster, cheaper and more efficient than traditional modes; and new demands from audiences, who want to access contents where, when and the way(s) they want. Thus, unlike the other four strategic decision options discussed above, each of which may evince advantages or disadvantages in different situations, the general trend throughout the communications sector is towards multiplatform content distribution.

\section{Hypotheses and Methodology}

Our research is based on the following hypotheses referred to the media and entertainment companies:

H1: Inorganic growth allows for a faster increase in revenues but involves higher levels of indebtedness than organic growth.

$\mathrm{H} 2$ : Vertical integration generates lower Return on Investment (ROI) than horizontal integration: If there is a bottleneck in the market, media corporations may be forced to be vertically integrated, and it is expected to generate revenue streams or greater economy efficiency. However, such strategy will lead towards a loss of specialization and efficiency.

H3: Internationalization increases the profitability of audiovisual companies.

H4: Specialization in a type of business can generate rates of income growth inferior to those obtained from the offer of a more diversified business portfolio.

H5: Traditional players are also moving into new digital territories by acquiring companies with digital capabilities or developing their own 
digital platforms. Such strategy allows the firms to enlarge their scope and their economies of scale.

\section{The sample}

The basic indicators of the 50 largest listed companies in the media and entertainment sector are analyzed for the purposes of this paper. The main criteria used to select companies and databases were transparency, company size, and a trajectory that enables study of the consequences of strategies chosen over long periods of time (at least 15 years). To ensure that data are historically comparable, only listed companies have been included in the sample (listed from 2010 to 2016, at least).

The Thomson Reuters Mergers and Acquisitions Database was used. In particular, correlations between growth models and four success indicators are traced: the evolution of market share, revenues, profitability, and indebtedness.

The North American Industry Classification System (NAICS) criteria have been used to identify the following sectors as pertaining to the audiovisual market: cable and other subscription programming, television broadcasting, and motion picture and video production. In light of a later quality control process, a number of companies that belong to the "Broadcasting" sector as defined by Thomson were also included in the sample: specifically, Comcast, Charter, and Discovery.

All the corporate operations (mergers and acquisitions) undertaken by these companies have been taken into consideration in this analysis. The Thomson Reuters database was the source again in this regard, but its contents were filtered according to a set of criteria designed for the purposes of this study, as follows:

a. Operations that are listed in the annual accounts filed by companies have been added, even though they do not feature in the Thomson Reuters database.

b. Investment figures have been included for those companies that published such amounts in formal or informal terms. Where no such 
information is available, the amount may be assumed to be small because companies are required to report any operations that have or may have a significant impact on their business.

c. Operations have been categorized by sector within the audiovisual industry, in line with the industrial criteria established by Thomson.

The companies analyzed for the purposes of this paper are listed in Appendix 1. These 50 companies are based in 17 different countries, generating total revenues of USD397 billion and an Earnings Before Interest and Taxes (EBIT) value of USD75 billion in 2016, and they represent $88 \%$ of global television revenue (Ofcom, 2017). Appendix 2 shows the countries of origin of the companies.

As it is clear from the information presented in Table 2, in terms of value (revenue, market capitalization and EBIT) most of the companies addressed here are based in the US market. This fact must be taken into account in analyzing the data and drawing conclusions, because only a few, very large companies may influence the overall results. Therefore, insofar as possible, this analysis works with unweighted averages.

The results for the 50 companies have been compared with those for a number of previously defined groups, which were not mutually exclusive. The groups were defined in line with the following criteria:

a. Geography (local or international), depending on the relative weight of international sales in 2016 as a proportion of total sales. International companies are firms in which over $30 \%$ of income is generated internationally, and local companies are firms in which $100 \%$ of the income is generated locally.

b. Diversification or specialization strategy, measured by the Herfindhal Index (HHI) as applied to different units of the business in 2016 (Noam, 2016). Diversified companies have lower HHI indices in 2016 in relation to the weight of the different units of the business within the total income for the group, while specialized companies have higher 
HHI indices in 2016 in relation to the weight of the different units of the business within the total income for the group.

c. Strategy for growth (inorganic or organic), as a function of the degree to which the volume of the firm's acquisitions between 2010 and 2016 amount to a higher percentage or a lower percentage in relation to the total value of the company.

After the results, a more detailed account of the geographical context in which corporate operations take place is shown, as well as the kinds of operations that strengthen the value chain, the most profitable strategies for growth, and the profitability of operations relating to vertical or horizontal integration.

\section{Indicators assessed}

Doyle (2018) asserts that "in the context of media industries, the difficulties of defining success and sustainability and of pinpointing suitable measures of performance are manifold and well recognized" (p. 3). We have chosen the standard economic and financial performance, but we are concerned that in media companies there are other non-economic indicators that are also important, such as quality values, audiences, audience satisfaction, consumer welfare awards, critical reception for outputs, capacity to engage, managers' subjective assessments (Wirth \& Bloch, 1995; Papadakis \& Thanos, 2010; Urgellés, 2017).

Different levels of growth, profitability and debt have been compared to the average values detailed below. Simple averages have been used to ensure that differences in company size do not distort the results. The criteria used can be seen in Appendix 3.

\section{Results}

The results for the measures outlined above are presented in Table 1, which takes into consideration whether the companies are local or international, diversified or specialized, and whether or not they have implemented inorganic or organic strategies for growth. After the presentation of results, a more detailed account of the following issues is offered: the geographical 
context in which corporate operations take place; the kinds of operations that strengthen the value chain; the most profitable strategies for growth; and finally, the profitability of operations relating to vertical or horizontal integration.

\section{Table 1. Main results across different clusters from the $\mathbf{5 0}$ audiovisual companies (2010-2016)}

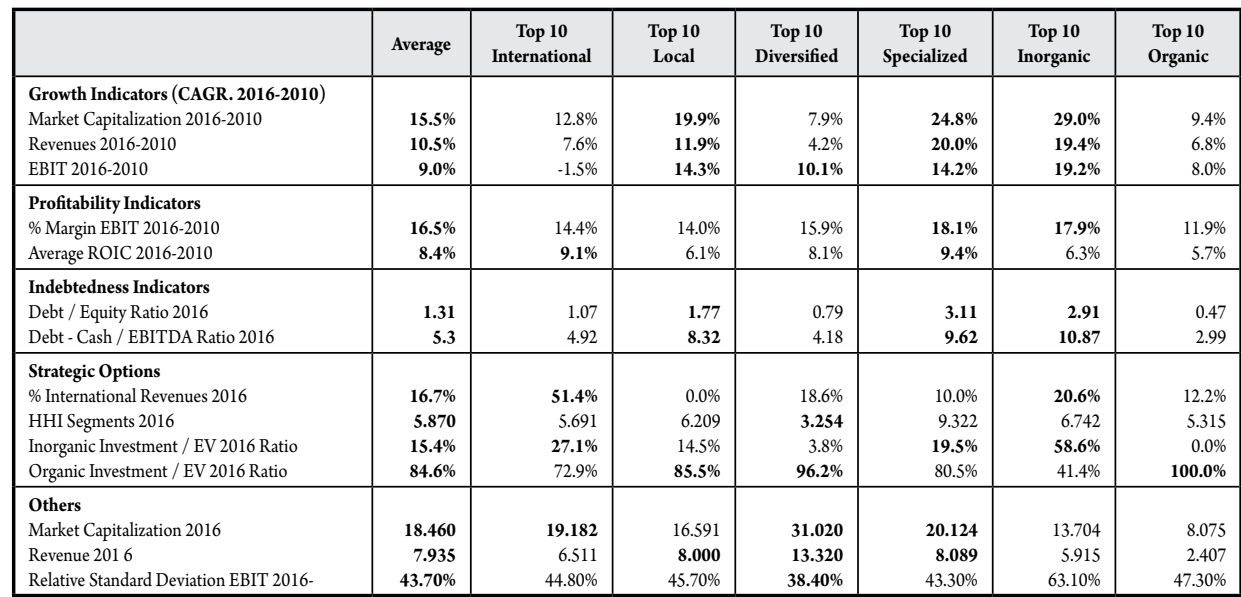

Source: Own elaboration from NAICS database ${ }^{4}$.

As Peltier (2004) averred, specialization and inorganic growth appear to be the strategic decisions that lead to greatest growth in terms of revenues, market capitalization and results (EBIT) of media companies. International companies and specialized audiovisual companies evinced higher levels of profitability in terms of ROIC for the period covered by this study. However, this was not the case for international firms as regards the EBIT percentage margin. Local media companies show higher levels of growth in terms of revenues, market capitalization and results (EBIT) than international companies - that is, they grow more quickly.

As regards indebtedness, companies that opt for inorganic growth or specialization show higher levels of debt. Likewise, local companies tend to have higher levels of indebtedness. More diversified companies show great-

4 Market Capitalization Growth calculated as a comparison between the one at the end of $2016 \mathrm{vs}$ the one at the end of 2010. The calculation for Revenues and EBIT are made using the fiscal year amounts for the selected years of each company. 
er stability in their results (EBIT Coefficient of Variation) as well as higher margins; such stability also correlates with larger companies. Based on the data in Table 1, the top ten diversified companies have a lower EBIT coefficient of variation (standard deviation of EBIT/average), a higher EBIT margin (16.5\% vs. $15.1 \%)$, and their market capitalization is also higher than the average (USD31.02 billion vs. USD18.46 billion). More diversified companies report significantly lower levels of debt.

\section{Corporate operations}

Mergers and acquisitions carried out by some of the fifty companies included in the sample have been analyzed (500 corporate operations in total). Table 2 shows the numbers of operations by region for both acquirers and acquired companies. Regional operations are those carried out in the company's own region, while trans-regional operations are those undertaken outside the company's country of origin.

\section{Table 2. Volume of transactions among audiovisual companies by region (2010-2016)}

\begin{tabular}{|l|r|r|r|r|}
\hline Acquirer Grand Region & \multicolumn{1}{c|}{ Regional } & Transregional & \multicolumn{1}{c|}{ Total } & \% Transregional vs. Total \\
\hline North America & 127.657 & 6.263 & 133.920 & $4,68 \%$ \\
\hline Europe & 17.244 & 1.025 & 18.269 & $5,61 \%$ \\
\hline Asia & 9.042 & 44 & 9.086 & $0,48 \%$ \\
\hline Latam & 3.375 & 1.200 & 4.575 & $26,23 \%$ \\
\hline Africa & 0 & 1.349 & 1.349 & $100,00 \%$ \\
\hline Total general & $\mathbf{1 5 7 . 3 1 8}$ & $\mathbf{9 . 8 8 1}$ & $\mathbf{1 6 7 . 1 9 9}$ & $\mathbf{5 , 9 1 \%}$ \\
\hline
\end{tabular}

Source: Own elaboration from NAICS database ${ }^{5}$.

While North American companies are more prevalent in numerical terms, European companies predominate in terms of activity. Most corporate operations took place within each company's region. It is striking that, although one of main means of international growth is via corporate operations, the level of trans-regional investment is minimal, with the exception of Africa and Latin America.

5 Volume of transactions considered as the total amount of the deal (deal size) for every operation analyzed during the years between 2010 and 2016. 


\section{Value chain}

The fifty companies in the sample have been classified in three broad categories depending on their main line of business or their original core business if a dominant activity is not apparent: multichannel video program distributor (MVPDs), television networks, and entertainment production. Each of these sectors maps onto a stage in the value chain. This classification enables distinctions as to how many operations have been undertaken by a given company within its own sector and how many have been carried out in forms of business development that are outside the company's core business. As Table 3 shows, in terms of value, the trend is towards operations centering on the company's own sector; however, in terms of activity, there are more operations focused on product development. In other words, major operations are implemented for the purpose of gaining greater power within known markets, while fewer operations are undertaken with the aim of entering new markets.

\section{Table 3. Classification of operations by industry of the target (2010-2016)}

\begin{tabular}{|c|c|c|c|c|}
\hline & $\begin{array}{c}\text { Deal size } M \\
\text { (USD) }\end{array}$ & $\%$ vs Total & $\begin{array}{l}\text { Number of } \\
\text { Operations }\end{array}$ & $\%$ vs Total \\
\hline Multichannel Video Programming Distributor & 99.622 & $60 \%$ & 40 & $8 \%$ \\
\hline Entertaiment Production & 18.684 & $11 \%$ & 133 & $26 \%$ \\
\hline Infratructure Real State \& Equipment & 7.702 & $5 \%$ & 17 & $3 \%$ \\
\hline Advertising \& Marketing & 1.094 & $1 \%$ & 20 & $4 \%$ \\
\hline Diversified Industrial \& Consumer Goods & 698 & $0 \%$ & 7 & $1 \%$ \\
\hline Radio & 466 & $0 \%$ & 11 & $2 \%$ \\
\hline Newspaper \& Magazine Publishing & 0 & $0 \%$ & 4 & $1 \%$ \\
\hline
\end{tabular}

Source: Own elaboration from NAICS database ${ }^{6}$.

From the perspective of the industrial sector, the data indicates that cable providers in the United States have been the main targets of acquisition operations. The second most prevalent target is television networks. In terms of activity, the highest number of acquisitions took place in the entertainment products $(26 \%)$ and digital and e-commerce $(24 \%)$ sectors.

6 Volume of transactions considered as the total amount of the deal (deal size) for every operation analyzed during the years between 2010 and 2016 . 
Different patterns of investment are disclosed by an analysis of the various industrial sub-sectors in Table 4.

\section{Table 4. Destination of transactions made by MVPDS by industry (2010-2016)}

\begin{tabular}{|l|r|r|r|r|}
\hline & Deal size (M USD)2 & \% vs. Total & Number of Operations & \% vs. Total \\
\hline Multichannel Video Programing Distributor & 97.717 & $81 \%$ & 32 & $22 \%$ \\
Entertainment Production & 7.990 & $7 \%$ & 33 & $23 \%$ \\
Infratructure Real State \& Equipment & 5.501 & $5 \%$ & 9 & $6 \%$ \\
Television Networks & 4.336 & $4 \%$ & 14 & $10 \%$ \\
Technology & 3.008 & $2 \%$ & 27 & $19 \%$ \\
Digital Medla and E- Commerce & 1.119 & $1 \%$ & 18 & $13 \%$ \\
Advertising \& Marketing & 771 & $1 \%$ & 5 & $3 \%$ \\
Diversified Industrial \& Consumer Goods & 344 & $0 \%$ & 3 & $2 \%$ \\
Radio & 0 & $0 \%$ & 1 & $1 \%$ \\
Newspaper \& Magazine Publishing & 0 & $0 \%$ & 1 & $1 \%$ \\
\hline Total General & $\mathbf{1 2 0 . 7 8 6}$ & & $\mathbf{1 4 3}$ & \\
\hline
\end{tabular}

Source: Own elaboration from NAICS database ${ }^{7}$.

Table 5 presents the operations carried out by MVPD firms. The deal size of acquisitions for distributors is high due to Charter's acquisition of the Time Warner Company in 2016 (USD78.3 billion). However, even if that operation is excluded, MVPDs have devoted most of their efforts to gaining market share in the distribution sector. Nevertheless, concerns regarding contents are likewise noteworthy: Production is the second most important target of investment, and it ranks first in terms of activity.

Table 5. Destination of transactions made by TV
networks by industry (2010-2016)

\begin{tabular}{|l|r|r|r|r|}
\hline & Deal size (M USD) & \% vs. Total & Number of Operations & \% vs. Total \\
\hline Television Networks & 18.373 & $59 \%$ & 69 & $24 \%$ \\
Digital Media and E-Commerce & 4.075 & $13 \%$ & 84 & $30 \%$ \\
Entertainment Production & 3.729 & $12 \%$ & 74 & $26 \%$ \\
Infratructure Real State \& Equipment & 2.201 & $7 \%$ & 8 & $3 \%$ \\
Multichannel Video Programming Distributor & 1.440 & $5 \%$ & 7 & $2 \%$ \\
Radio & 466 & $2 \%$ & 10 & $4 \%$ \\
Diversified Industrial \& Consumer Goods & 354 & $1 \%$ & 4 & $1 \%$ \\
Advertising \& Marketing & 323 & $1 \%$ & 13 & $5 \%$ \\
Technology & 64 & $0 \%$ & 10 & $4 \%$ \\
Newspaper \& Magazine Publishing & 0 & $0 \%$ & 3 & $1 \%$ \\
\hline Total General & $\mathbf{3 1 . 0 2 4}$ & & $\mathbf{2 8 2}$ & \\
\hline
\end{tabular}

Source: Own elaboration from NAICS database ${ }^{8}$.

7 Volume of transactions considered as the total amount of the deal (deal size) for every operation analyzed during the years between 2010 and 2016.

8 Volume of transactions considered as the total amount of the deal (deal size) for every operation analyzed during the years between 2010 and 2016. 
As Table 6 indicates, increasing market share is also the main aim of television networks; but the primary concern in that regard is growth in the digital environment, which comprises $13 \%$ of total investment and $30 \%$ of the corporate operations undertaken.

\section{Table 6. Destination of transactions made by entertainment production by industry (2010-2016)}

\begin{tabular}{|l|c|c|c|c|}
\hline \multicolumn{1}{|c|}{ Acquirer: Entertainment Production } & Deal size (M USD)2 & \% vs. Total & Number of Operations & \% vs. Total \\
\hline Entertainment Production & 6.965 & $45 \%$ & 26 & $34 \%$ \\
Television Networks & 5.905 & $38 \%$ & 20 & $26 \%$ \\
Digital Media and E- Commerce & 1.047 & $7 \%$ & 17 & $22 \%$ \\
Technology & 1.007 & $7 \%$ & 11 & $14 \%$ \\
Multichannel Video Programming Distributor & 465 & $3 \%$ & 1 & $1 \%$ \\
Advertising \& Marketing & 0 & $0 \%$ & 2 & $3 \%$ \\
\hline Total general & $\mathbf{1 5 . 3 8 9}$ & & 77 & \\
\hline
\end{tabular}

Source: Own elaboration from NAICS database ${ }^{9}$.

Production companies have spent least on increasing their power within the entertainment production sector, as we can see in Table 7; they have tended to invest in other sectors, first in television, followed by digital development.

\section{Table 7. Classification of operations intrasectorial vs. intersectorial (2010-2016)}

\begin{tabular}{|c|c|c|c|c|c|c|c|c|c|c|}
\hline \multirow[b]{2}{*}{ Acquirer Category } & \multicolumn{2}{|c|}{ Intra-sectorial } & \multicolumn{2}{|c|}{ Inter-sectorial } & \multicolumn{2}{|c|}{ Intra-sectorial } & \multicolumn{2}{|c|}{ Inter-sectorial } & \multirow{2}{*}{$\begin{array}{c}\text { Total } \\
\text { Deal size } \\
\text { (M USD) }\end{array}$} & \multirow[b]{2}{*}{$\begin{array}{l}\text { Number of } \\
\text { Operations }\end{array}$} \\
\hline & $\begin{array}{l}\text { Deal size } \\
\text { (M USD) }\end{array}$ & $\begin{array}{l}\text { Number of } \\
\text { Operations }\end{array}$ & $\begin{array}{l}\text { Deal size } \\
\text { (M USD) }\end{array}$ & $\begin{array}{l}\text { Number of } \\
\text { Operations }\end{array}$ & $\begin{array}{l}\text { Deal size } \\
\text { (M USD) }\end{array}$ & $\begin{array}{l}\text { Number of } \\
\text { Operations }\end{array}$ & $\begin{array}{l}\text { Deal size } \\
\text { (M USD) }\end{array}$ & $\begin{array}{l}\text { Number of } \\
\text { Operations }\end{array}$ & & \\
\hline $\begin{array}{l}\text { Multichannel Video Programming Distributor } \\
\text { Television Networks } \\
\text { Entertainment Production }\end{array}$ & $\begin{array}{r}97.717 \\
18.373 \\
6.965\end{array}$ & $\begin{array}{l}32 \\
69 \\
26\end{array}$ & $\begin{array}{r}23.069 \\
12.651 \\
8.424\end{array}$ & $\begin{array}{r}111 \\
213 \\
51\end{array}$ & $\begin{array}{l}81 \% \\
59 \% \\
45 \%\end{array}$ & $\begin{array}{l}22 \% \\
24 \% \\
34 \%\end{array}$ & $\begin{array}{l}19 \% \\
41 \% \\
55 \%\end{array}$ & $\begin{array}{l}78 \% \\
76 \% \\
66 \%\end{array}$ & $\begin{array}{r}120.786 \\
31.024 \\
15.389\end{array}$ & $\begin{array}{r}143 \\
282 \\
77\end{array}$ \\
\hline Total & 123.055 & 127 & 44.144 & 375 & $74 \%$ & $25 \%$ & $26.4 \%$ & $74.7 \%$ & 167.199 & 502 \\
\hline
\end{tabular}

Source: Own elaboration from NAICS database ${ }^{10}$.

\section{Strategies for inorganic growth}

Crosschecking the two databases enables assessment of which corporate strategy for growth has generated better returns, based on the Ansoff (1957)

9 Volume of transactions considered as the total amount of the deal (deal size) for every operation analyzed during the years between 2010 and 2016 .

10 Volume of transactions considered as the total amount of the deal (deal size) for every operation analyzed during the years between 2010 and 2016 . 
matrix. We can also identify which strategies may have facilitated horizontal or vertical growth.

Ansoff distinguishes if growth occurs within the same geographical market or with respect to the same products. On that basis, he defines the following fundamental strategies for growth: a) market penetration: same products and same markets; b) market development: same products, different geographical markets; c) product development: different products, same geographical markets; and d) diversification: different products, different geographical markets.

Given this framework, twenty companies showing more intense levels of mergers and acquisitions activity (higher number of acquisitions vs. enterprise value) have been analyzed. The aim is to explore to what extent such operations contribute to one of these strategies for growth, in which the acquirer is operating in the same geographical market or produces the same product. In Table 8, lists of the top five companies have been drawn up, ranked in accordance with the percentage of total investment spent on market penetration, market development, product development and diversification. Finally, each of these groups has likewise been studied in relation to the indicators of growth, profitability and indebtedness outlined in the previous section, so as to trace the results obtained via their inorganic strategies for growth.

In terms of profitability, companies that have focused on a market development strategy generated bigger margins and a higher ROIC than the average, due to the effect of economies of scope and scale. This conclusion conflicts with the results presented in Table 1, where the top ten international companies had decreased in terms of EBIT and results for the period addressed in this study. Nevertheless, the figures in Table 8 are congruent with economic theory: Firms that acquire companies in other countries usually benefit from economies of scale. 


\section{Table 8. Main results across different strategic options for growth of top 50 audiovisual companies (2010-2016)}

\begin{tabular}{|c|c|c|c|c|c|c|}
\hline & $\begin{array}{l}\text { Average } 50 \\
\text { Companies }\end{array}$ & $\begin{array}{c}\text { Top } 10 \\
\text { Inorganic }\end{array}$ & $\begin{array}{c}\text { Top } 5 \\
\text { Concentration }\end{array}$ & $\begin{array}{l}\text { Top } 5 \text { Product } \\
\text { Development }\end{array}$ & $\begin{array}{l}\text { Top } 5 \text { Market } \\
\text { Development }\end{array}$ & $\begin{array}{c}\text { Top } 5 \\
\text { Diversification }\end{array}$ \\
\hline $\begin{array}{l}\text { Growth Indicators (CAGR. 2016-2010) } \\
\text { Market Capitalization 2016-2010 } \\
\text { Revenues 2016-2010 } \\
\text { EBIT 2016-2010 }\end{array}$ & $\begin{array}{r}15.5 \% \\
10.5 \% \\
9.0 \%\end{array}$ & $\begin{array}{l}29.0 \% \\
19.4 \% \\
19.2 \%\end{array}$ & $\begin{array}{l}34.5 \% \\
22.9 \% \\
21.3 \%\end{array}$ & $\begin{array}{r}21.7 \% \\
13.4 \% \\
3.5 \%\end{array}$ & $\begin{array}{r}26.7 \% \\
16.9 \% \\
8.6 \%\end{array}$ & $\begin{array}{r}15.3 \% \\
1.0 \% \\
-4.7 \%\end{array}$ \\
\hline $\begin{array}{l}\text { Profitability Indicators } \\
\% \text { Margin EBIT } 2016 \\
\text { Average ROIC 2016-2010 }\end{array}$ & $\begin{array}{r}15.1 \% \\
8.4 \%\end{array}$ & $\begin{array}{r}15.6 \% \\
6.3 \%\end{array}$ & $\begin{array}{r}19.9 \% \\
8.5 \%\end{array}$ & $\begin{array}{r}13.1 \% \\
8.2 \%\end{array}$ & $\begin{array}{r}23.7 \% \\
8.7 \%\end{array}$ & $\begin{array}{r}16.5 \% \\
9.4 \%\end{array}$ \\
\hline $\begin{array}{l}\text { Indebtedness Indicators } \\
\text { Debt / Equity Ratio } 2016 \\
\text { Debt - Cash / EBITDA Ratio } 2016\end{array}$ & $\begin{array}{l}1.31 \\
5.30\end{array}$ & $\begin{array}{r}2.91 \\
10.87\end{array}$ & $\begin{array}{r}4.86 \\
11.42\end{array}$ & $\begin{array}{l}1.85 \\
6.86\end{array}$ & $\begin{array}{l}1.54 \\
4.77\end{array}$ & $\begin{array}{l}1.22 \\
2.24\end{array}$ \\
\hline $\begin{array}{l}\text { Strategic Options } \\
\text { \% International Revenues } 2016 \\
\text { HHI Segments } 2016 \\
\text { Inorganic Investment / EV 2016 Ratio } \\
\text { Organic Investment / EV 2016 Ratio }\end{array}$ & $\begin{array}{r}16.7 \% \\
5.870 \\
15.4 \% \\
84.6 \%\end{array}$ & $\begin{array}{r}20.6 \% \\
6.742 \\
58.6 \% \\
41.4 \%\end{array}$ & $\begin{array}{r}0.3 \% \\
8.650 \\
47.5 \% \\
52.5 \%\end{array}$ & $\begin{array}{r}14.2 \% \\
6.531 \\
35.2 \% \\
64.8 \%\end{array}$ & $\begin{array}{r}\mathbf{3 7 . 5} \% \\
\mathbf{4 . 8 6 1} \\
26.4 \% \\
\mathbf{7 3 . 6} \%\end{array}$ & $\begin{array}{r}\mathbf{3 5 . 1} \% \\
\mathbf{5 . 1 8 9} \\
22.3 \% \\
77.7 \%\end{array}$ \\
\hline $\begin{array}{l}\text { Others } \\
\text { Market Capitalization } 2016 \\
\text { Revenue } 2016 \\
\text { Relative Standard Deviation EBIT 2016-2010 }\end{array}$ & $\begin{array}{r}18.460 \\
7.935 \\
43.7 \%\end{array}$ & $\begin{array}{r}13.704 \\
5.915 \\
63.1 \%\end{array}$ & $\begin{array}{r}17.790 \\
7.288 \\
59.1 \%\end{array}$ & $\begin{array}{r}11.183 \\
5.493 \\
37.0 \%\end{array}$ & $\begin{array}{r}7.359 \\
3.584 \\
26.0 \%\end{array}$ & $\begin{array}{r}11.696 \\
5.253 \\
36.3 \%\end{array}$ \\
\hline
\end{tabular}

Source: Own elaboration from NAICS database ${ }^{11}$.

\section{Horizontal and vertical integration}

The analytical process outlined above has also been applied in looking into growth strategies on vertical versus horizontal integration. The results presented in Table 9 show that horizontal integration tends to be more profitable than vertical integration; however, horizontal integration is a more aggressive strategy, as it tends to lead to higher levels of corporate indebtedness.

\section{Table 9. Main results across different strategic options for growth (horizontal/vertical) (2010-2016)}

\begin{tabular}{|l|r|r|r|r|}
\hline & \multicolumn{1}{|c|}{$\begin{array}{c}\text { Average 50 } \\
\text { Companies }\end{array}$} & $\begin{array}{c}\text { Top 10 } \\
\text { Inorganic }\end{array}$ & \multicolumn{1}{c|}{ Horizontal } & \multicolumn{1}{c|}{ Vertical } \\
\hline Growth Indicators (CAGR. 2016-2010) & & & & \\
Market Capitalization 2016-2010 & $\mathbf{1 5 . 5 \%}$ & $29.0 \%$ & $\mathbf{2 7 . 2} \%$ & $14.8 \%$ \\
Revenues 2016-2010 & $\mathbf{1 0 . 5} \%$ & $19.4 \%$ & $\mathbf{2 2 . 1} \%$ & $7.9 \%$ \\
EBIT 2016-2010 & $\mathbf{9 . 0 \%}$ & $19.2 \%$ & $\mathbf{2 2 . 3} \%$ & $-1.0 \%$ \\
\hline Profitability Indicators & & & & \\
\% Margin EBIT 2016 & $\mathbf{1 5 . 1 \%}$ & $15.6 \%$ & $\mathbf{2 1 . 2} \%$ & $13.2 \%$ \\
Average ROIC 2016-2010 & $\mathbf{8 . 4} \%$ & $6.3 \%$ & $\mathbf{9 . 7} \%$ & $8.7 \%$ \\
\hline
\end{tabular}

11 Market capitalization growth calculated as a comparison between the one at the end of 2016 vs. the one at the end of 2010. The calculation for Revenues and EBIT are made using the fiscal year amounts for the selected years of each company. 


\begin{tabular}{|l|r|r|r|r|}
\hline & \multicolumn{1}{|c|}{$\begin{array}{c}\text { Average 50 } \\
\text { Companies }\end{array}$} & $\begin{array}{c}\text { Top 10 } \\
\text { Inorganic }\end{array}$ & Horizontal & \multicolumn{1}{|c|}{ Vertical } \\
\hline Indebtedness Indicators & & & & \\
Debt / Equity Ratio 2016 & $\mathbf{1 . 3 1}$ & 2.91 & $\mathbf{3 . 0 4}$ & 1.29 \\
Debt - Cash / EBITDA Ratio 2016 & $\mathbf{5 . 3}$ & 10.87 & $\mathbf{8 . 5 0}$ & 5.04 \\
\hline Strategic Options & & & & \\
\% International Revenues 2016 & $\mathbf{1 6 . 7 \%}$ & $20.6 \%$ & $17.5 \%$ & $22.8 \%$ \\
HHI Segments 2016 & $\mathbf{5 . 8 7 0}$ & 6.742 & 7.082 & 6.152 \\
Inorganic Investment / EV 2016 Ratio & $\mathbf{1 5 . 4 \%}$ & $58.6 \%$ & $43.7 \%$ & $29.0 \%$ \\
Organic Investment / EV 2016 Ratio & $\mathbf{8 4 . 6 \%}$ & $41.4 \%$ & $56.3 \%$ & $71.0 \%$ \\
\hline Others & & & & \\
Market Capitalization 2016 & $\mathbf{1 8 . 4 6 0}$ & 13.704 & 12.145 & 10.732 \\
Revenue 2016 & $\mathbf{7 . 9 3 5}$ & 5.915 & 5.214 & 5.181 \\
Relative Standard Deviation EBIT 2016-2010 & $\mathbf{4 3 . 7 \%}$ & $63.1 \%$ & $50.0 \%$ & $40.5 \%$ \\
\hline
\end{tabular}

Source: Own elaboration from NAICS database ${ }^{12}$.

\section{Conclusions and Managerial Implications}

In light of the analyses carried out above, the hypotheses formulated for the purposes of this research may now be tested in relation to the fifty companies that have undertaken the highest number of corporate operations in recent years.

$\mathrm{H} 1$ is confirmed by the analysis presented in this paper. As Table 1 shows, the increase in revenues generated via inorganic growth (19\% CAGR) is higher than that generated via organic growth (7\% CAGR). At the same time, however, the level of indebtedness is also higher. Our conclusion also refuses Peltier's (2004) reasoning about the negative correlation between size and performance. Our data shows that, in a period of seven years, media companies that developed growth strategies based on mergers and acquisitions increased their EBIT by $19 \%$ per year.

$\mathrm{H} 2$ has also been confirmed by the data presented in this paper. Vertical integration generates a lower ROIC than horizontal integration, although the return is quite similar. The difference is bigger in relation to the EBIT margin. The increase in profit margins at companies that integrated horizontally over the period of time covered by this study was $21 \%$, as

12 Market Capitalization Growth calculated as a comparison between the one at the end of 2016 vs. the one at the end of 2010. The calculation for revenues and EBIT are made using the fiscal year amounts for the selected years of each company. 
compared with just $13 \%$ for companies that integrated vertically. It seems that the increase of fixed costs associated to vertical integrations is not balanced by the main rationale behind this strategy: to raise a company's profitability through the sum of the profit margin earned at the different stages of the production and commercialization processes (Sánchez-Tabernero \& Carvajal, 2002).

As our third hypothesis suggests, internationalization increases the profitability of audiovisual companies. ROIC is higher in firms that have grown internationally, as compared to those that have grown locally. The results are different for more internationalized companies in comparison to companies that have centered their inorganic strategy for growth more intensively on internationalization. The hypothesis is not confirmed in relation to the former. Thus, the outcome for $\mathrm{H} 3$ in this study is inconclusive: It is confirmed in relation to ROIC but not in terms of margin. The international companies do not have a greater margin in terms of EBIT. This conclusion coincides with Peltier's (2004), who assumed a positive correlation between internationalization and economic performance. Certainly, the internationalization for production companies has the risk of producing contents for the international markets and no to focus towards the concerns of domestic audiences (Esser, 2016).

Our fourth hypothesis - specialization in a type of business leads towards lower growth rates - cannot be confirmed on the basis of the results presented in this paper. Although the increase in revenues is significantly higher in specialized companies (20\%) than in diversified companies (4\%), the margin involved is similar in both. When the specialization is in business terms, the rates of growth are higher.

Finally, we assumed that traditional players were moving into new digital territories by acquiring or merging companies with digital capabilities or developing their own digital business units (hypothesis 5). In accordance with Verhoeven, von Rimscha, Krebs, Siegert, and Sommer (2018), we thought that media firms were enhancing their scope by enhancing their distribution channels, aiming at both achieving economies of scale and increasing efficiency. However, such trend is not dominant. Most media companies 
are not taking high risks in the new digital markets. Though the number of operations is high (24\%), the deal size means just $4 \%$ of total investments.

The following conclusions may be drawn from the discussion of the results above, which prompt reflection on the possible causes and effects in relation to honing a competitive edge through corporate operations. In terms of ROIC, international companies and specialized companies show higher indices of profitability. As Chan-Olmsted and Chang (2003) and Doyle (2018) already concluded, this advantage is due to the effective exploitation of economies of scope and scale.

The internationalization of audiovisual companies increases their profitability because content distribution costs are low and a wide variety of such contents—cinema, music, television series, some sports - "translate" easily to other markets outside the country in which they were produced. This enables the development of an international brand identity capable of attracting large international audiences.

The fact that such growth is not reflected in terms of margin/EBIT proves that not every international company benefits from economies of scope and scale, especially if the audiovisual contents they offer are not attractive to audiences beyond the original market. The uncertainty inherent in the audiovisual market makes it difficult to predict the success of specific contents (Medina, Sánchez-Tabernero, \& Arrese, 2016; Medina \& Herrero, 2013).

According to the analysis detailed above, diversified companies tend to have the lowest levels of indebtedness. This finding appears to confirm the general theory regarding diversification (Makides \& Williamson, 1994), especially in unrelated sectors, that diversification is driven by a surplus of financial resources.

We discover a big variety of competitive situations when we analyze specific sectors. The cable industry tends towards a natural monopoly: In the time-period covered by this study, $60 \%$ of acquisitions were in the distribution sector. Other operations are oriented to guarantee the rights of exclusive contents that may attract consumers. On the other hand, the 
digital transformation of the media market explains why digital development and e-commerce companies have emerged as targets of investment among traditional media operators (Gutierrez-Rentería \& López, 2014). Corporate operations across sectors are likewise noteworthy: Television networks and entertainment production have acquired digital companies. For Chalaby (2016), the disruption of Internet has been one of the most important causes of vertical integration operations in the last years. However, such investments are still weak, probably because they are not yet enough profitable in comparison with their current core business (Picard, 2014).

The production sector has not invested heavily in acquiring external production companies because most managers prefer to develop talent in house in order to protect internal culture. In addition, audiovisual production is both expensive and risky; thus, production companies have less capital to devote to expanding their business, and tend to re-invest in their own resources, to ensure the quality of the contents they produce.

Growth is one of the main targets of every company as it is directly related to its value: The higher the cash flows of the company will be in the future, the higher the net present value. But managers usually face some challenges when choosing their strategic options to grow. The first one is uncertainty: There is no golden rule for growth, because one strategic option can fit very well to a particular company and can be inefficient for another. A second challenge is that growth is not for free: It requires resources and can be expensive depending on the strategy chosen and the cost of capital for the company; usually growth and debt are two terms intrinsically related.

Our research sets a good frame for analysis for managers of media companies who face the challenges of corporate growth: We show that mergers and acquisitions can generate rapid growth but is expensive in terms of ROIC and usually increases the leverage of the company; we provide data which demonstrate that internationalization is not always a source of competitive advantage; and we come to the conclusion that concentration strategies are the best option for increasing profit margins while vertical integrations must answer to any other needs than growth or profitability. 


\section{Limitations and Further Research}

A number of the limitations in this study relate to the sample selected for analysis. The selection criteria are open to question because although the rationale underpinning them is outlined in the methodology section, the criteria correspond primarily to the pragmatic interests of the researchers. Future studies might usefully deploy statistical cluster analysis to classify the companies addressed. The sample size may seem small for the purposes of some analyses as the deal size of operations at some of the companies has a significant bearing on the sample and may distort the results.

At the same time, a seven-year time-lag was introduced in an attempt to cover a period as close as possible to the present. This study could be improved in the future, broadening its scope in terms of historical data. The time-period might be extended to ensure that the findings are not conditioned by the immediate economic context, as another study has averred.

Any analysis of international growth must encompass the geographical origins of both acquirer and acquired companies because different financial scenarios may account for such developments in different ways. The analysis carried out for the purposes of this paper centers on the consolidated data of defined clusters rather than the data of specific companies.

The conclusions of this paper, which appear to be coherent and congruent with the theory of company growth, should also be validated in relation to other industrial sectors, thus enabling an understanding of whether some of these conclusions are specific to the media market as such. At the same time, the conclusions drawn here are general in nature: It remains to be seen to what extent specific cases reflect the general theory or might be better framed as exceptions due to contextual conditions or company size.

Finally, while the database used is wide-ranging and consistent, it would benefit from further refinement as regards industrial classification and the amount or value of the operations involved. A media industry database could be used for future research in this field. Research into other industries and in-depth study of a number of key cases would also serve to 
consolidate the general theory outlined and invalidate any factors that may distort this widely accepted approach.

We have analyzed the efficiency of growth strategies of media companies. However, we have not paid attention to their effects on society. For instance, concentration may have negative consequences since the point of view of content pluralism and market competition. Vertical integration can cause that a few companies may be able to monopolize the market. Therefore, it may reduce choice for consumers. Furthermore, mergers and acquisitions may be oriented and get dominant positions in the market. Those relevant effects of corporate growth strategies deserve further policy-oriented pieces of research.

\section{References}

Albarran, A. B., \& Dimmick, J. (1996). Concentration and economics of multiformity in the communication industries. Journal of Media Economics, 9(4), 41-50. DOI: https://doi.org/10.1207/ s15327736me0904_3

Aldrich, H., \& Auster, E. R. (1986). Even dwarfs started small: Liabilities of age and size and their strategic implications. Research in organizational behavior, 8, 165-186. Retrieved from https://psycnet. apa.org/record/1988-12412-001

Allocca, M. A., \& Kessler, E. H. (2006). Innovation speed in small and medium-sized enterprises. Creativity and Innovation Management, 15(3), 279-295. DOI: https://doi.org/10.1111/j.14678691.2006.00389.x

Ansoff, I. (1957). Strategies for diversification. Harvard Business Review, 35(5), 113-124. Retrieved from http://sgpwe.izt.uam.mx/files/ users/uami/sppc/130/Gestion_y_Control_Estrategico_I/Lectura_10._Ansoff_Igor_Strategies_for_Diversification.pdf 
Buzzell, R. D., Gale, B. T., \& Sultan, R. G. (1975). Market share - a key to profitability. Harvard Business Review, 53(1), 97-106. Retrieved from https://hbr.org/1975/01/market-share-a-key-to-profitability

Carayannis, E. G., \& Rakhmatullin, R. (2014). The quadruple/quintuple innovation helixes and smart specialisation strategies for sustainable and inclusive growth in Europe and beyond. Journal of the Knowledge Economy, 5(2), 212-239. DOI: https://doi.org/10.1007/ s13132-014-0185-8

Carman, J. M., \& Langeard, E. (1980). Growth strategies for service firms. Strategic Management Journal, 1(1), 7-22. DOI: https://doi. org/10.1002/smj.4250010103

Carvajal, M., \& García Avilés, J. A. (2008). From newspapers to multimedia groups: Business growth strategies of the regional press in Spain. Journalism Practice, 2(3), 453-462. DOI: https://doi. org/10.1080/17512780802281198

Casero-Ripollés, A., \& Izquierdo-Castillo, J. (2013). Between decline and a new online business model: The case of the Spanish newspaper industry. Journal of Media Business Studies, 10(1), 63-78. DOI: https://doi.org/10.1080/16522354.2013.11073560

Chalaby, J. K. (2016). Television and globalization: The TV content global value chain. Journal of Communication, 66(1), 35-59. DOI: https://doi.org/10.1111/jcom.12203

Chalaby, J. (2018). Hedging against disaster: Risk and mitigation in the media and entertainment industries. International Journal of Digital Television 9(2), 167-184. DOI: https://doi.org/10.1386/ jdtv.9.2.167_1

Chan-Olmsted, S. M., \& Chang, B. H. (2003). Diversification strategy of global media conglomerates: Examining its patterns and deter- 
minants. The Journal of Media Economics, 16(4), 213-233. DOI: https://doi.org/10.1207/s15327736me1604_1

Chon, B. S., Choi, J., Barnett, G., Danowski, J. A., \& Joo, S. H. (2003). A structural analysis of media convergence: Cross-industry mergers and acquisitions in the information industries. Journal of $\mathrm{Me}$ dia Economics, 16(3), 141-157. DOI: https://doi.org/10.1207/ s15327736me1603_1

Coad, A., Daunfeldt, S. O., Hölzl, W., Johansson, D., \& Nightingale, P. (2014). High-growth firms: Introduction to the special section. Industrial and Corporate Change, 23(1), 91-112. DOI: https:// doi.org/10.1093/icc/dtt052

Cronin Jr., J. J., \& Page Jr., T. J. (1988). An examination of the relative impact of growth strategies on profit performance. European Journal of Marketing, 22(1), 57-68. DOI: https://doi.org/10.1108/ eum0000000005268

D’Annunzio, A. (2017). Vertical integration in the TV market: Exclusive provision and program quality. International Journal of Industrial Organization, 53, 114-144. DOI: https://doi.org/10.1016/j.ijindorg.2017.05.002

Doyle, G. (2018). Television production: Configuring for sustainability in the digital era. Media, Culture \& Society, 40(2), 285-295. DOI: https://doi.org/10.1177/0163443717717634

Doyle, G. (2015). Multi-platform media and the miracle of the loaves and fishes. Journal of Media Business Studies, 12(1), 49-65. DOI: https://doi.org/10.1080/16522354.2015.1027113

Esser, A. (2016). Challenging US leadership in entertainment industries? The rise and sale of Europe's international TV production groups. International Journal of Communications, 10,3585-3614. Retrieved from https://ijoc.org/index.php/ijoc/article/view/4809 
Evens, T., \& Donders, K. (2016). Mergers and acquisitions in TV broadcasting and distribution: Challenges for Competition, industrial and media policy. Telematics and Informatics, 33(2), 674-682. DOI: https://doi.org/10.1016/j.tele.2015.04.003

Gutiérrez-Rentería, M. E., \& López Hernández, C. E. (2014). La convergencia digital propicia convergencia entre industrias: principales empresas que participan en el mercado de capitales concentran los mayores ingresos en 2013. Revista de Comunicación 13, 144162. Retrieved from https://dialnet.unirioja.es/servlet/articulo? codigo $=4875645$

Hendriks, P. (1995). Communications policy and industrial dynamics in media markets: Toward a theoretical framework for analyzing media industry organization. Journal of Media Economics, 8(2), 61-76. DOI: https://doi.org/10.1207/s15327736me0802_6

Jung, J., \& Chan-Olmsted, S. (2005). Impacts of media conglomerates' dual diversification on financial performance. Journal of Media Economics, 18(3), 183-202. DOI: https://doi.org/10.1207/ s15327736me1803_2

Kerr, J., \& Slocum, J. W. (1987). Managing corporate culture through reward systems. The Academy of Management Executive, 1(2), 99107. DOI: https://doi.org/10.5465/ame.1987.4275817

Kolo, C., \& Vogt, P. (2003). Strategies for growth in the media and communications industry: Does size really matter? International Journal on Media Management, 5(4), 251-261. DOI: https://doi. org/10.1080/14241270309390041

Krugman, P. (1980). Scale economies, product differentiation, and the pattern of trade. The American Economic Review, 70(5), 950-959. Retrieved from https://www.jstor.org/stable/1805774 
Lawler, E. E. (1997). Rethinking organization size. Organizational Dynamics, 26(2), 24-35. DOI: https://doi.org/10.1016/s00902616(97)90003-6

Makidies, C. C., \& Williamson, P. J. (1994). Related diversification, core competences and core performance. Strategic Management Journal, 15(S2), 149-165. DOI: https://doi.org/10.1002/ smj.4250151010

Matsusaka, J. G. (2001). Corporate diversification, value maximization, and organizational capabilities. The Journal of Business, 74(3), 409-431. DOI: https://doi.org/10.1086/321932

Medina, M., Sánchez-Tabernero, A., \& Arrese, A. (2016). Content as products in media markets. In G. F Lowe \& C. Brown (Ed.), Managing media firms and industries. what's so special about media management? (pp. 243-261). Heidelberg, Germany: Springer-Verlag. DOI: https://doi.org/10.1007/978-3-319-08515-9_14

Medina, M., \& Herrero, M. (2013). Keys to monetize social media in the audiovisual business. In M. Friedrichsen, \& W. Mühl-Benninghaus (Eds.), Handbook of social media management value chain and business models in changing media markets (pp. 311-325), Berlin, Germany: Springer. DOI: https://doi.org/10.1007/978-3-642-28897-5_18

Noam, E. (2016). Who owns the world's media? Media concentration and ownership around the world. Oxford, UK: Oxford University Press. DOI: https://doi.org/10.1093/acprof:oso/9780199987238.001.0001

Ofcom. (2017). International communications market report. Retrieved from https://www.ofcom.org.uk/research-and-data/multi-sector-research/cmr/cmr-2017/international

Oliver, J. (2014). Dynamic capabilities and superior firm performance in the UK media industry. Journal of Media Business Studies, 11(2), 57-78. DOI: https://doi.org/10.1080/16522354.2014.11073580 
Papadakis, V. M., \& Thanos, I. C. (2010). Measuring the performance of acquisitions: An empirical investigation using multiple criteria. British Journal of Management, 21(4), 859-873. DOI: https://doi. org/10.1111/j.1467-8551.2009.00671.x

Peltier, S. (2004). Mergers and acquisitions in the media industries: Where failures really unforseeable? Journal of Media Economics, 17(4), 261-278. DOI: https://doi.org/10.1207/s15327736me1704_2

Picard, R. (2014). Twilight or new dawn of journalism?: Evidence from the changing news ecosystem. Journalism Studies, 15(5), 1-11. DOI: https://doi.org/10.1080/1461670X.2014.895530

PwC. (2016). Global entertainment and media outlook 2016-2020: A world of differences. PwC. Retrieved from https://www.pwc.com.tr/ $\mathrm{tr} /$ industry/entertainment-media/outlook-global-entertainment-and-media-outlook-2016-2020.pdf

Roos, J., \& von Krogh, G. (2016). Managing strategy processes in emergent industries: The case of media firms. Heidelberg, Germany: Springer.

Sánchez-Tabernero, A., \& Carvajal, M. (2002). Media concentration in the European market. New trends and challenges. Pamplona, Spain: Servicio de publicaciones de la Universidad de Navarra.

Schlesinger, P., \& Doyle, G. (2015). From organizational crisis to multi-platform salvation? Creative destruction and the recomposition of news media. Journalism, 16(3), 305-323. DOI: https://doi. org/10.1177/1464884914530223

Schmalensee, R. (1981). Economies of scale and barriers to entry. Journal of political Economy, 89(6), 1228-1238. Retrieved from http:// www.jstor.org/stable/1837192 
Schwartz, H., \& Davis, S. M. (1981). Matching corporate culture and business strategy. Organizational Dynamics, 10(1), 30-48. DOI: https://doi.org/10.1016/0090-2616(81)90010-3

Stigler, G. J. (1958). The economies of scale. The Journal of Law and Economics, 1(1) 54-71. DOI: https://doi.org/10.1086/466541

Storper, M. (1989). The transition to flexible specialisation in the US film industry: external economies, the division of labour, and the crossing of industrial divides. Cambridge Journal of Economics, 13(2), 273305. DOI: https://doi.org/10.1093/oxfordjournals.cje.a035094

Urgellés, A. (2017). From attention to engagement in the battle for the audiences. In M. Medina (Ed.), Current and emerging issues in the audiovisual industry (pp. 97-117). London, UK: ISTE-Wiley. DOI: https://doi.org/10.1002/9781119384632

Van Kranenburg, H. \& Ziggers, G. W. (2018). Mergers and acquisitions and their performance. In A. Albarran, B. Mierzejewska \& J. Jung, Handbook of media economics and media management (pp. 201218). New York, NY: Routledge.

Verhoeven, M., von Rimscha, M. B., Krebs, I., Siegert, G., \& Sommer, C. (2018). Identifying paths to audience success of media products: The media decision-makers' perspective. International Journal on Media Management, 20(1), 51-77. DOI: https://doi.org/10.108 $0 / 14241277.2017 .1402019$

Wirtz, B. W. (2001). Reconfiguration of value chains in converging media and communications markets. Long Range Planning, 34(4), 489506. DOI: http://dx.doi.org/10.1016/S0024-6301(01)00066-8

Wirth, M. \& Bloch, H. (1995). Industrial organization theory and media industry analysis. Journal of Media Economics, 8(2), 15-26. DOI: https://doi.org/10.1207/s15327736me0802_3 
Yoo, C.S. (2002). Vertical integration and media regulation in the new economy. Yale Journal on Regulation, 19(1), 171-295. Retrieved from http://digitalcommons.law.yale.edu/yjreg/vol19/iss1/5

\section{Appendixes}

\section{Appendix 1. Selection of companies analyzed}

\begin{tabular}{|c|c|c|}
\hline \# & COMPANY NAME & REVENUES IN 2016 (FY, MILL. USD) \\
\hline 1 & Comcast Corp & 80.403 \\
\hline 2 & Walt Disney Co & 55.632 \\
\hline 3 & Time Warner Inc & 29.318 \\
\hline 4 & Charter Communications Inc & 29.003 \\
\hline 5 & Twenty-First Century Fox Inc & 28.500 \\
\hline 6 & Sky PLC & 16.823 \\
\hline 7 & DISH Network Corp & 15.095 \\
\hline 8 & CBS Corp & 13.166 \\
\hline 9 & Viacom Inc & 12.488 \\
\hline 10 & Vivendi SA & 11.374 \\
\hline 11 & Netflix Inc & 8.831 \\
\hline 12 & RTL Group SA & 6.557 \\
\hline 13 & Discovery Communications Inc & 6.497 \\
\hline 14 & Naspers Ltd & 6.098 \\
\hline 15 & Fuji Media Holdings Inc & 5.872 \\
\hline 16 & Grupo Televisa SAB & 4.648 \\
\hline 17 & Prosiebensat 1 Media SE & 3.994 \\
\hline 18 & Shaw Communications Inc & 3.912 \\
\hline 19 & Mediaset SpA & 3.855 \\
\hline 20 & ITV PLC & 3.780 \\
\hline 21 & Nippon Television Holdings Inc & 3.741 \\
\hline 22 & Scripps Networks Interactive Inc & 3.401 \\
\hline 23 & Lions Gate Entertainment Corp & 3.202 \\
\hline 24 & Tokyo Broadcasting System Holdings Inc & 3.191 \\
\hline
\end{tabular}




\begin{tabular}{|c|c|c|}
\hline$\#$ & COMPANY NAME & REVENUES IN 2016 (FY, MILL. USD) \\
\hline 25 & Oriental Pearl Media Co Ltd & 2.801 \\
\hline 26 & Sinclair Broadcast Group Inc & 2.737 \\
\hline 27 & TV Asahi Holdings Corp & 2.656 \\
\hline 28 & Kabel Deutschland Holding AG & 2.459 \\
\hline 29 & Cyfrowy Polsat SA & 2.326 \\
\hline 30 & Television Francaise 1 SA & 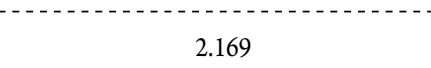 \\
\hline 31 & Toho Co Ltd & 2.071 \\
\hline 32 & SKY Perfect JSAT Holdings Inc & 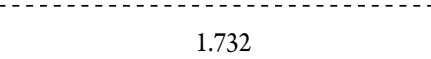 \\
\hline 33 & Cogeco Communications Inc & 1.661 \\
\hline 34 & Modern Times Group MTG AB & 1.647 \\
\hline 35 & Entertainment One Ltd & 1.358 \\
\hline 36 & Metronole TelevisionSA & 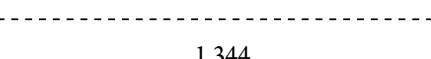 \\
\hline $\begin{array}{c}36 \\
-\ldots-\end{array}$ & Metropole Television SA & 1.344 \\
\hline 37 & CJ E\&M Corp & 1.275 \\
\hline 38 & Toei Co Ltd & 1.153 \\
\hline 39 & Nexstar Media Group Inc & 1.103 \\
\hline 40 & Hunan TV \& Broadcast Intermediary Co Ltd & $-1-1-1-10$ \\
\hline & (1) & 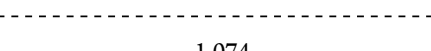 \\
\hline $\begin{array}{r}41 \\
---1\end{array}$ & Atresmedia Corporacion de Medios de Comunicacion SA & 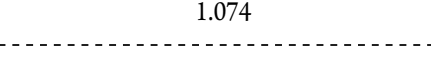 \\
\hline 42 & Mediaset Espana Comunicacion SA & 1.036 \\
\hline 43 & Zee Entertainment Enterprises Ltd & 992 \\
\hline 44 & Shochiku Co Ltd & 853 \\
\hline 45 & Megacable Holdings SAB de CV & 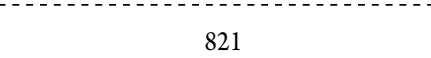 \\
\hline 46 & World Wrestling Entertainment Inc & 729 \\
\hline 47 & TiVo Corp & 649 \\
\hline 48 & Zhejiang Huace Film \& TV Co Ltd & 640 \\
\hline & - & 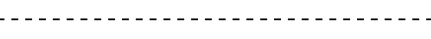 \\
\hline 49 & CITIC Guoan Information Industry Co Ltd & 566 \\
\hline 50 & Elang Mahkota Teknologi Tbk PT & $-1--1-10$ \\
\hline
\end{tabular}

Source: own elaboration from NAICS database. 


\section{Appendix 2. Main indicators selected audiovisual companies}

\begin{tabular}{|c|c|c|c|c|}
\hline Country & $\begin{array}{l}\text { Enterprice Value } \\
2016 \text { (MM USD) }\end{array}$ & Numbers of Firms & $\begin{array}{c}\text { Total Revenues } \\
2016 \text { (MM USD) }\end{array}$ & $\begin{array}{c}\text { EBIT } 2016(M M \\
\text { USD) }\end{array}$ \\
\hline United States of America & 668.349 & 16 & 288.726 & 61.905 \\
\hline United Kingdom & 34.186 & 2 & 22.637 & 2.993 \\
\hline Japan & 18.663 & 8 & 19.091 & 1.668 \\
\hline France & 29.803 & 3 & 15.662 & 987 \\
\hline Luxembourg & 11.844 & 1 & 6.898 & 1.260 \\
\hline Canada & 13.100 & 3 & 6.597 & 1.383 \\
\hline Germany & 19.178 & 2 & 6.592 & 1.458 \\
\hline Mexico & 16.698 & 2 & 6.064 & 1.196 \\
\hline South Africa & 60.264 & 1 & 5.930 & 28 \\
\hline China & 20.689 & 4 & 5.316 & 523 \\
\hline Italy & 5.166 & 1 & 4.056 & -59 \\
\hline Poland & 3.990 & 1 & 2.468 & 423 \\
\hline Spain & 6.711 & 2 & 2.219 & 452 \\
\hline Sweden & 2.103 & 1 & 1.752 & 124 \\
\hline Korea; Republic (S. Korea) & 2.358 & 1 & 1.326 & 24 \\
\hline India & 5.682 & 1 & 889 & 226 \\
\hline Indonesia & 4.219 & 1 & 553 & 106 \\
\hline TOTAL & 923.001 & 50 & 396.775 & 74.698 \\
\hline
\end{tabular}

* Ranked by enterprise value as at the end of 2016. Total revenues and EBIT regard to the Fiscal Year of 2016 for each company.

Source: Own elaboration from NAICS data base.

\section{Appendix 3. Description of indicators assessed}

- $\quad$ Magnitude of growth, the Compound Annual Growth Rate (CAGR) over the period 2010-2016 has been compared for the following variables:

Market capitalization: This is taken as the main measure of what the company is worth to its shareholders. The fact that this variable does not take company debt into account cannot be overlooked; however, the results are very similar to those that might be expected from an analysis of the evolution of the company's enterprise value.

Total revenue: Total income at the company for each fiscal year. 
EBIT: Although it is less common, the EBIT rather than the EBITDA has been selected as a measure because it is a more uniform value in the media market; some media companies regard expenditure on contents as a cost that may be written off, while others see it as an operation cost.

- Measures of profitability: Simple average values have been calculated for the following indicators, for the years 2010-2016:

EBIT percentage margin: The EBIT percentage margin in relation to the revenue generated in each fiscal year.

ROIC: The percentage value remaining when after-tax profits have been divided by the total long-term liabilities (shareholder equity + financial debt).

- Measures of indebtedness: Value for the following indicators have been established up to the year 2016:

Debt/Equity ratio 2016: This ratio is calculated by dividing the company's total liabilities by its shareholder equity, and indicates the degree to which the company is financed by its own or external resources. The higher the ratio, the higher the level of indebtedness.

Debt/EBITDA ratio 2016: This is a standard indicator that expresses the company's ability to pay off its incurred debt in relation to its EBITDA. In light of the measures of profitability outlined above, the EBIT might also be used as a measure in this regard; but given that the Debt/EBITDA ratio is a standard measure that remains fixed even in relation to the conditions shaping a company's level of indebtedness, this latter value has been selected instead.

- Measures of strategic options: A number of indicators to measure the degree to which each company has opted for different strategies for growth have been selected for the purposes of this paper: 
Percentage of internationalization 2016: The percentage of total revenues generated though sales outside the company's country of origin. Most companies report this figure; if companies do not report this figure, it is assumed that there are no such sales. 2016 was selected as the reference year because the indicator may then be read as the outcome of the strategy applied by the company in the preceding years.

2016 Herfindhal Index applied to the units or areas of the business: The Herfindhal Index is applied in this case to the relative weights of the various units or areas of which the company is comprised (the sum of the different weightings squared). The index is an accepted measure of market concentration, and may thus be read as a measure of the relative concentration of the different business actions within a given company. For the purposes of calculation, the baseline figure is the revenue generated by each company in 2016.

Inorganic growth/Enterprise value ratio: This ratio is the result of dividing the total number of corporate operations for the period 2010 2016 into the total enterprise value for 2016, and is read as a measure that indicates whether the company's current value is determined by inorganic growth.

Organic growth/Enterprise value ratio: This ratio is a complement to the one defined above (Inorganic growth/Enterprise value ratio); the value of a company that reports no corporate operation of significant magnitude is understood to depend on organic growth.

- Measures of size and other factors: A number of indicators have been selected to measure the average size of the companies included in the sample.

Market Capitalization: The company's average market capitalization value in USD (absolute numbers) in 2016. 
Revenues: The company's average revenues in USD (absolute numbers) in 2016.

EBIT Coefficient of Variation 2010-2016: This indicator measures the volatility of the results for the period 2010-2016; it is calculated by dividing the standard deviation of the results by their average value. 